\title{
Wpływ użytego uszczelniacza kanałowego, cementu i irygacji alkoholem izopropylowym na siłę łączenia wkładów z włókna szklanego z zębiną korzeniową
}

\author{
Influence of the used root canal sealer, cement and isopropyl alcohol irrigation \\ on the bonding strength of glass fiber post and cores with root dentine
}

\author{
Katedra Protetyki Stomatologicznej, Klinika Protetyki i Technologii Dentystycznych, \\ Uniwersytet Medyczny im. Karola Marcinkowskiego w Poznaniu \\ Department of Prosthodontics, Clinic of Prosthodontics and Dental Technology, \\ Poznan University of Medical Sciences, Poland
}

DOI: http://dx.doi.org/10.20883/df.2021.1

\section{STRESZCZENIE}

Wstęp. Wkłady koronowo-korzeniowe wzmacniane włóknem szklanym są powszechnie stosowane w celu odtworzenia retencji dla uzupełnień zachowawczych i protetycznych. Najczęściej powstającym niepowodzeniem w przypadku ich stosowania jest utrata retencji, stąd istotne jest określenie tych czynników, które mogą na nią oddziaływać.

Cel pracy. Celem prowadzonych badań było porównanie siły retencji wkładów koronowo-korzeniowych wzmocnionych włóknem szklanym z użyciem cementu konwencjonalnego (RelyX Ultimate Clicker, 3M ESPE) i cementu samoadhezyjnego (RelyX U200, 3M ESPE) oraz ocena wpływu past uszczelniających (Endomethasone N, AH Plus) na cementy żywiczne. Ponadto zbadano skuteczność oczyszczania ścian kanału obturowanego Endomethasone $\mathrm{N}$ 70\% alkoholem izopropylowym.

Materiał i metody. Do badań użyto 48 bydlęcych stałych siekaczy pozyskanych od krów w wieku 2 lat. Przygotowane próbki poddano testowi na „zrywanie" przy użyciu uniwersalnej maszyny wytrzymałościowej Hounsfield H5 KS model HTE S/N D 83281 (f-my Tinius Olsen, Wielka Brytania).

Wyniki. Użycie cementów samoadhezyjnych osłabiało mocowanie o 20-37\%. Z kolei siły potrzebne do zerwania wkładów z kanałów obturowanych pastą na bazie eugenolu były niższe o 18,5-34\%. Płukanie 70\% alkoholem izopropylowym pozwoliło na zmniejszenie negatywnego wpływu eugenolu.

Wnioski. Wykazano, że zarówno rodzaj zastosowanego cementu, jak i pasty uszczelniającej kanał ma wpływ na siłę mocowania wkładów koronowo-korzeniowych.

Słowa kluczowe: wkłady koronowo-korzeniowe, wkłady z włókna szklanego, uszczelniacz kanałowy na bazie eugenolu.

\section{ABSTRACT}

Introduction. Fibre-reinforced composite posts (FRC) are frequently used to increase retention of composite and prosthetic restorations. The most frequent failure occurring in the group of teeth rebuilt with the FRC posts is loss of retention. Hence, it is important to find those factors that may influence it.

Aim of the study. The aim of the study was to compare the bonding strength of FRC posts luted with the use of conventional cement (RelyX Ultimate Clicker, 3M ESPE) and self-adhesive cement (RelyX U200, 3M ESPE) and to evaluate the effect of sealing pastes (Endomethasone N, AH Plus) on resinous cements. Also, the effectiveness of cleaning the root canal walls obstructed by Endomethasone $\mathrm{N}$ with $70 \%$ isopropyl alcohol was tested.

Material and methods. Forty eight bovine mandibular incisors were collected from cows aged two years. A pullout test was performed using a universal testing machine Hounsfield H5 KS, HTE S/N D 83281 (Tinius Olsen, UK).

Results. The use of self-adhesive cements weakened the bonding by $20-37 \%$. The pull out strengths needed to remove the posts from the root canals covered with eugenol-based paste were lower by $18.5-34 \%$. Rinsing with $70 \%$ isopropyl alcohol allowed to reduce the negative effect of eugenol.

Conclusions. It was concluded that both, the type of cement and root canal sealer have an impact on the luting strength of the post and core.

Keywords: posts and cores, glass fiber posts, eugenol root canal sealers. 


\section{Wstęp}

Odbudowa protetyczna z użyciem wkładów koronowo-korzeniowych (k-k) jest powszechnie stosowaną metodą rekonstrukcji zębów ze znacznym zniszczeniem korony klinicznej. W celu zwiększenia retencji dla przyszłego uzupełnienia oraz lepszego rozkładu naprężeń zalecane jest wykonanie wkładów k-k w przypadku utraty powyżej 50\% tkanek zęba (Żarow 2009). Wraz z rozwojem stomatologii estetycznej i technik adhezyjnych w miejsce wkładów metalowych (lanych lub standardowych) coraz częściej stosowane są wkłady kompozytowe wzmocnione włóknem szklanym ( $z$ ang. Fibre Reinforced Composite - FRC) (Vallittu 2017). Zbudowane są z włókien szklanych (SiO2) lub krzemionkowych (białe lub przezroczyste) o średnicy 8-20 $\mu \mathrm{m}$ (w ilości około 60\%) zatopionych w żywicach epoksydowych lub metakrylanowych (KacprzakOgłuszka 2018, Mierzwińska-Nastalska 2011, Akkayan 2004, Dejak 2014). Moduł sprężystości sztyftów FRC zbliżony do tkanek zęba (około $40 \mathrm{GPa}$ ), wiąże się z mniejszym ryzykiem pęknięcia korzenia w porównaniu $z$ ich metalowymi odpowiednikami (Clavijo 2009, Schmitter 2011). Należą one do grupy wkładów pasywnych - jedynym czynnikiem zapewniającym retencję jest "cement" adhezyjny służący do ich mocowania (Monticelli 2003).

Założeniem prowadzonych badań było sprawdzenie, jak uproszczenie procedury cementowania dzięki użyciu cementu samoadhezyjnego (w porównaniu z cementem stosowanym $w$ technice total etch) wpływa na siłę wiązania w układzie zębina korzeniowa-materiał mocujący-wkład k-k FRC. Porównano także oddziaływanie uszczelniacza kanałowego ( $z$ dodatkiem eugenolu lub na bazie żywic epoksydowych) na uzyskane wartości sił zrywu. Zbadano również, czy płukanie kanałów uszczelnionych pastą z zawartością eugenolu $70 \%$ alkoholem izopropylowym wpływa na zmianę wartości uzyskanych naprężeń zrywających.

\section{Metody}

Do badań wybrano 48 dolnych siekaczy bydlęcych o podobnej anatomii. Korzenie po ekstrakcji oczyszczono kiretami ręcznymi, a następnie przechowywano $w$ wodzie destylowanej $w$ temperaturze $4^{\circ} \mathrm{C}$. Wodę zmieniano co tydzień. Zęby poddano badaniu w ciągu dwóch tygodni od ich ekstrakcji. Korony zębów zostały odcięte poniżej połączenia szkliwno-zębinowego. Korzenie poddano leczeniu endodontycznemu narzędziami ręcznymi oraz maszynowymi pilnikami reciprocalnymi o rozmiarze przy wierzchołku $\varnothing 40 \mathrm{i}$ roz- bieżności 0,4 (przy użyciu endomotoru VDW Gold). Mechaniczne opracowanie kanałów było wspomagane irygacją podchlorynem sodu 2,5\%, 40\% kwasem cytrynowym oraz solą fizjologiczną. Kanały wypełniono gutaperką oraz wybranym materiałem uszczelniającym.

Zęby podzielono na 6 grup $(n=8)$. Kanały w grupach $1 \mathrm{AU}$ i $2 \mathrm{AUC}$ uszczelniono pastą na bazie żywic epoksydowych AH Plus (Dentsply Maileffer, Niemcy) (oznaczenie " $A$ "), w grupach 3EU, 4EUC, 5EU*, 6EUC* preparatem Endomethasone $\mathrm{N}$ (Septodont, Francja) (oznaczenie "E"). W grupie $5 E^{*}$ i $6 E^{*}$ kanały przed osadzeniem wkładu przepłukano $70 \%$ alkoholem izopropylowym (oznaczenie grupy ${ }^{*}{ }^{* \prime)}$.

Do badania użyto wkładów Fibrekleer 4X o średnicy 1,375 mm (Pentron), które osadzono na głębokość $10 \mathrm{~mm}$. Preparację kanału pod wkład wykonano z użyciem wierteł Peeso IV oraz wiertła dedykowanego dla użytego wkładu. W grupie $1 \mathrm{AU}, 3 \mathrm{EU}, 5 \mathrm{EU} *$ wkłady mocowano $z$ użyciem cementu RelyX U200 (3M, cement samoadhezyjny, podwójny mechanizm utwardzania) - oznaczenie grupy „U”. Cement przy ujściu naświetlano lampą polimeryzacyjną przez 40 sekund.

W grupach 2AUC, 4EUC, 6EUC* wkłady cementowano $\mathrm{z}$ zastosowaniem RelyX Ultimate Clicker (3M, cement konwencjonalny, podwójny mechanizm utwardzania) - oznaczenie prób "UC". Osadzenie wkładu poprzedzało wytrawianie $37 \%$ kwasem fosforowym przez 20 sekund, dokładne płukanie wodą destylowaną, osuszanie ćwiekami papierowymi oraz podwójna aplikacja Single Bond Universal Adhesive do wnętrza kanału z użyciem microbrusha. Delikatnie osuszono kanał powietrzem wolnym od oleju i używając papierowych sączków usunięto nadmiar żywicy. Systemu wiążącego nie naświetlano. Po zmieszaniu materiału RelyX Ultimate Clicker na papierowym bloczku, wprowadzono go do wnętrza kanału przy użyciu igły Lentulo. Cement polimeryzowano lampą przez 40 sekund.

Korzenie z zacementowanymi wkładami poddano testowi „zrywania” wkładu za pomocą uniwersalnej maszyny wytrzymałościowej Hounsfield H5 KS model HTE S/N D 83281 (f-my Tinius Olsen, Wielka Brytania), przy użyciu głowicy o sile $5000 \mathrm{~N}$ i prędkości jej przesuwu $0,5 \mathrm{~mm} / \mathrm{min}$. Wytrzymałość na zrywanie była rejestrowana $\mathrm{w}[\mathrm{N}]$ oraz [MPa].

Zerwane wkłady poddano ocenie faktograficznej (w 10x powiększeniu, przy użyciu mikroskopu Leica M320) w celu oceny charakteru powstałego przełomu. 


\section{Wyniki}

Wyniki uzyskane w teście na zrywanie wkładu odnotowano w niutonach [N] i megapaskalach [MPa]. Zarejestrowane wartości przedstawiono w tabelach 1-2. Do przeprowadzenia analizy statystycznej wykorzystano program STATISTICA (data analysis software system), version 13 Dell Inc. (2016). Do porównań dwóch grup zastosowano test t-Studenta. Istotność statystyczną określono dla $\mathrm{p}<0,05$.

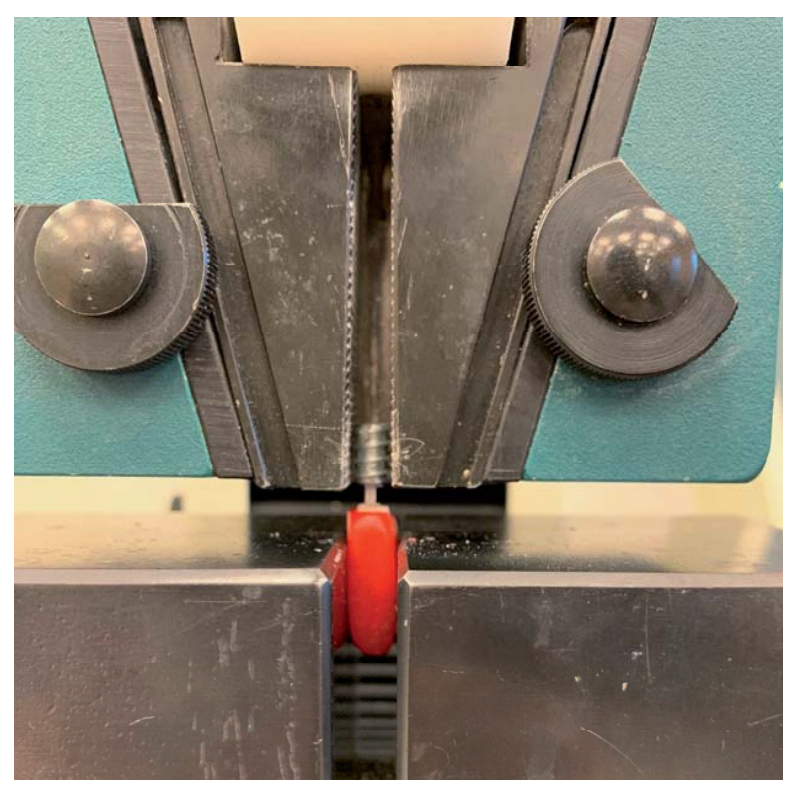

Rycina 1. Próba umieszczona w maszynie wytrzymałościowej Hounsfield H5 KS podczas testu zrywania Figure 1. Sample placed on the Hounsfield H5 KS testing machine during the pull out test

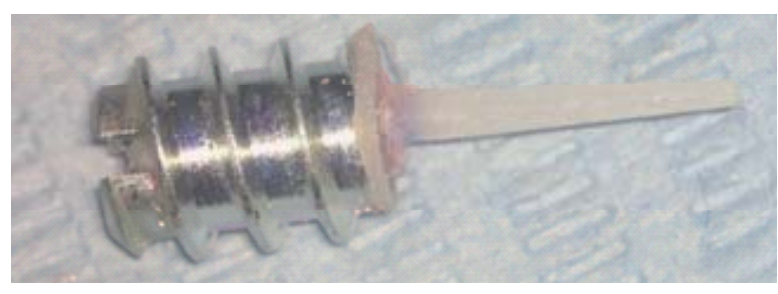

Rycina 2. Zerwany wkład - przełom adhezyjny A2 na granicy wkład - cement (RelyX Ultimate Clicker, AH Plus)

Figure 2. Post after testing - A2 adhesive break between post and cement (RelyX Ultimate Clicker, AH Plus)

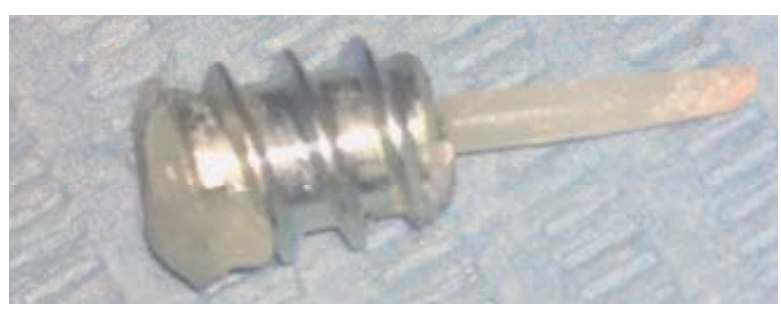

Rycina 3. Zerwany wkład - przełom adhezyjny A1 na granicy cement - zębina (RelyX U200, Endomethasone N) Figure 3. Post after testing - A1 adhesive fracture at the cement-dentin interface (RelyX U200, Endomethasone N)
Tabela 1. Zestawienie wartości sił potrzebnych do zerwania wkładu w zależności od następujących zmiennych: materiału mocującego i użytego uszczelniacza kanałowego. Wyniki podane w niutonach [N]

\begin{tabular}{|l|c|c|c|c|c|c|}
\hline $\begin{array}{c}\text { Badana } \\
\text { grupa }\end{array}$ & $\mathrm{n}$ & $\begin{array}{c}\text { Średnia } \\
{[\mathrm{N}]}\end{array}$ & $\begin{array}{c}\text { Mediana } \\
{[\mathrm{N}]}\end{array}$ & $\begin{array}{c}\text { Wartość } \\
\text { min. } \\
{[\mathrm{N}]}\end{array}$ & $\begin{array}{c}\text { Wartość } \\
\text { maks. } \\
{[\mathrm{N}]}\end{array}$ & $\begin{array}{c}\text { Odch. } \\
\text { st. }\end{array}$ \\
\hline 1AU & 8 & 309,1 & 305,35 & 282,4 & 342,4 & 21,4 \\
\hline 2AUC & 8 & 387,7 & 386,0 & 347,6 & 419,5 & 23,6 \\
\hline 3EU & 8 & 198,9 & 199,9 & 170,5 & 221,7 & 18,6 \\
\hline 4EUC & 8 & 316,0 & 316,3 & 279,0 & 354,1 & 27,0 \\
\hline 5EU* & 8 & 267,4 & 261,3 & 240,1 & 308,4 & 25,0 \\
\hline 6EUC & 8 & 347,8 & 355,6 & 306,0 & 372,5 & 24,2 \\
\hline
\end{tabular}

Tabela 2.Zestawienie wartości wytrzymałości połączenia pomiędzy wkładem k-k FRC, a zębiną korzeniową, w zależności od następujących zmiennych: materiału mocującego i użytego uszczelniacza kanałowego. Wyniki podane w megapaskalach [MPa]

\begin{tabular}{|l|c|c|c|c|c|c|}
\hline $\begin{array}{c}\text { Badana } \\
\text { grupa }\end{array}$ & $\mathrm{n}$ & $\begin{array}{c}\text { Średnia } \\
{[\mathrm{MPa}]}\end{array}$ & $\begin{array}{c}\text { Mediana } \\
{[\mathrm{MPa}]}\end{array}$ & $\begin{array}{c}\text { Wartość } \\
\text { min. } \\
{[\mathrm{MPa}]}\end{array}$ & $\begin{array}{c}\text { Wartość } \\
\text { maks. } \\
{[\mathrm{MPa}]}\end{array}$ & $\begin{array}{c}\text { Odch. } \\
\text { st. }\end{array}$ \\
\hline 1AU & 8 & 9,5 & 9,3 & 8,8 & 10,6 & 0,7 \\
\hline 2AUC & 8 & 12,0 & 12,0 & 10,8 & 13,0 & 0,7 \\
\hline 3EU & 8 & 6,2 & 6,3 & 5,3 & 6,9 & 0,6 \\
\hline 4EUC & 8 & 9,8 & 9,8 & 8,7 & 11,0 & 0,8 \\
\hline 5EU* & 8 & 8,3 & 8,1 & 7,5 & 9,6 & 0,8 \\
\hline 6EUC* & 8 & 10,8 & 11,1 & 9,5 & 11,6 & 0,8 \\
\hline
\end{tabular}

Analiza statystyczna wykazała, że zarówno rodzaj użytego uszczelniacza kanałowego, jak i cementu wpływał na uzyskane siły zrywające wkładów k-k (tabele 3 i 5). W przypadku osadzenia wkładu z użyciem materiału mocującego RelyX UItimate Clicker odnotowane wartości były średnio o 20\% (AH Plus) - 37\% (Endomethasone N) wyższe niż dla cementu RelyX U200. Z kolei zastosowanie uszczelniacza z zawartością eugenolu osłabiło wiązanie o $18,5 \%$ dla cementu RelyX Ulrimate Clicker i 34\% dla RelyX U200.

W grupie, w której kanały uszczelniono Endomethasone $\mathrm{N}$ i osadzono wkłady przy użyciu cementu samoadhezyjnego (RelyX U200), płukanie 70\% alkoholowym izopropylowy poprawiło siły adhezji o 26\%. Natomiast dla cementu RelyX Ultimate Clicker wynosiła odpowiednio 10\%. Siły zrywania pozostawały jednak niższe o około 10\% (RelyX Ultimate Clicker) - 15\% (RelyX U200) w porównaniu z kanałami uszczelnionymi pastą AH Plus. Nie stwierdzono istotności statystycznej w przypadku porównania grup 6EUC* z 4EUC (tabela 4). 
Tabea 3. Porównanie sił zrywających [N] w przypadku zastosowania różnych cementów (RelyX U200, RelyX Ultimate Clicker) przy stałym użytym uszczelniaczu kanałowym (Endomethasone N ub AH Plus)

\begin{tabular}{|l|c|}
\hline \multicolumn{1}{|c|}{ Porównywane grupy } & Istotność statystyczna* \\
\hline Endomethasone N & \\
\hline RelyX U200 vs RelyX UC** & $\mathrm{p}<0,001$ \\
\hline AH Plus & \\
\hline RelyX U200 vs RelyX UC & $\mathrm{p}<0,001$ \\
\hline
\end{tabular}

* $p<0,05$ - są istotne różnice statystyczne; $p>0,05$ - brak różnic statystycznych

** RelyX UC - RelyX Ultimate Clicker

Tabela 4. Porównanie wpływu płukania kanału alkoholem izopropylowym poprzedzającego osadzenie wkładu na wartość sił zrywających [N] w przypadku zastosowania materiału Endomethasone N, wybranego cementu (RelyX U200, RelyX Ultimate Clicker)

\begin{tabular}{|c|c|}
\hline Porównywane próby & Istotność statystyczna* \\
\hline RelyX U200, End vs alkohol & $\mathrm{p}<0,001$ \\
\hline RelyX UC ${ }^{* *}$, End vs alkohol & $\mathrm{p}>0,05$ \\
\hline
\end{tabular}

${ }^{*} p(p<0,05)=$ są istotne różnice statystyczne; $p>0,05=$ brak różnic statystycznych

**RelyX UC= RelyX Ultimate Clicker

Tabela 5. Porównanie wartości sił zrywania [N] w przypadku użycia tego samego materiału mocującego (RelyX U200, RelyX Ultimate Clicker) przy różnych uszczelniaczach kanałowych (Endomethasone N lub AH Plus)

\begin{tabular}{|l|c|}
\hline \multicolumn{1}{|c|}{ Badane próby } & Istotność statystyczna* \\
\hline $\begin{array}{l}\text { RelyX U200, End } \\
\text { U200, AH Plus }\end{array}$ & $\mathbf{p}<0,001$ \\
\hline $\begin{array}{l}\text { RelyX UC U**, End vs RelyX } \\
\text { UC, AH Plus }\end{array}$ & $\mathbf{p}<0,001$ \\
\hline
\end{tabular}

* $p<0,05=$ są istotne różnice statystyczne; $p>0,05=$ brak różnic statystycznych

**End $=$ Endomethasone $\mathrm{N}$

*** RelyX UC = RelyX Ultimate Clicker

Obserwacja zerwanych wkładów w powiększeniu wykazała zróżnicowany charakter powstałych uszkodzeń (tabela 6). Dla cementu RelyX Ultimate Clicker, niezależnie od zastosowanego uszczelniacza kanałowego, dominujący był przełom adhezyjny A2 - do zerwania połączenia doszło pomiędzy cementem łączącym a wkładem (62,5-75\%). Dla cementu samoadhezyjnego RelyX U200 stwierdzono 75-87,5\% przełomów adhezyjnych A1 - zerwanie połączenia pomiędzy zębiną korzeniową a cementem łączącym.
Tabela 6. Wyniki analizy powierzchni przełomów systemów łączących. A1: przełom adhezyjny - jeżeli doszło do zerwania połączenia pomiędzy zębiną korzeniową a cementem łączącym; A2: przełom adhezyjny - jeżeli doszło do zerwania połączenia pomiędzy cementem łączącym a wkładem; K: przełom kohezyjny - jeżeli pęknięcie przebiegało wewnątrz środka łączącego; A/K: przełom adhezyjno-kohezyjny (mieszany) - połączenie przełomu adhezyjnego i kohezyjnego

\begin{tabular}{|c|c|c|c|c|c|c|c|c|c|}
\hline \multirow{2}{*}{ Uszczelniacz } & \multirow{2}{*}{ Cement } & \multicolumn{2}{|c|}{$\mathrm{A} 1$} & \multicolumn{2}{|c|}{$\mathrm{A} 2$} & \multicolumn{2}{|c|}{ K } & \multicolumn{2}{|c|}{$\mathrm{A} / \mathrm{K}$} \\
\hline & & $\mathrm{N}$ & $\%$ & $\mathrm{~N}$ & $\%$ & $\mathrm{~N}$ & $\%$ & $\mathrm{~N}$ & $\%$ \\
\hline \multirow{4}{*}{$\begin{array}{l}\text { Endometha- } \\
\text { sone N }\end{array}$} & $\begin{array}{l}\text { RelyX } \\
\text { U200 }\end{array}$ & 7 & 87,5 & 0 & 0 & 0 & 0 & 1 & 12,5 \\
\hline & $\begin{array}{l}\text { RelyX } \\
\text { UC }\end{array}$ & 1 & 12,5 & 6 & 75 & 0 & 0 & 1 & 12,5 \\
\hline & $\begin{array}{l}\text { RelyX } \\
\text { U200* }\end{array}$ & 7 & 87,5 & 0 & 0 & 0 & 0 & 1 & 12,5 \\
\hline & $\begin{array}{c}\text { RelyX } \\
\text { UC* }\end{array}$ & 1 & 12,5 & 5 & 62,5 & 0 & 0 & 2 & 25 \\
\hline \multirow{2}{*}{ AH Plus } & $\begin{array}{l}\text { RelyX } \\
\text { U200 }\end{array}$ & 6 & 75 & 1 & 12,5 & 0 & 0 & 1 & 12,5 \\
\hline & $\begin{array}{c}\text { RelyX } \\
\text { UC }\end{array}$ & 1 & 12,5 & 6 & 75 & 0 & 0 & 1 & 12,5 \\
\hline
\end{tabular}

*oznaczono próby, w których kanały przed osadzeniem wkładów FRC płukano alkoholem izopropylowym

**RelyX UC= RelyX Ultimate Clicker

\section{Dyskusja}

Celem prowadzonych badań było porównanie siły mocowania cementu żywicznego konwencjonalnego $z$ materiałem samoadhezyjnym. Zbadano również wpływ past uszczelniających na bazie eugenolu oraz żywic epoksydowych na uzyskane siły zrywu. Zasadność kontroli wpływu uszczelniaczy kanałowych na siłę wiązania cementów wynika z doniesień o negatywnym działaniu eugenolu na przebieg polimeryzacji materiałów na bazie żywic. Sprawdzono, czy wpływ ten utrzymuje się pomimo mechanicznego opracowania kanału i czy może być ewentualnie zmniejszony poprzez płukanie kanału 70\% alkoholem izopropylowym.

Minimalna wytrzymałość wkładu na zrywanie, mogąca gwarantować sukces kliniczny, została oszacowana na około $200 \mathrm{~N}$ (Bonfante 2007). Próg ten został osiągnięty dla wszystkich badanych grup, poza próbą gdzie kanały uszczelniono Endomethasone $\mathrm{N}$, a wkłady osadzono $\mathrm{z}$ użyciem materiału samoadhezyjnego RelyX U200 - najniższa odnotowana wartość wynosiła 170,5 N, średnia 198,9 
N. W przeprowadzonych badaniach porównawczych, w sytuacji użycia cementów wymagających wcześniejszego wytrawienia tkanek zęba oraz użycia systemów wiążących, stwierdzono wyższe wartości sił wiązania (o około 20-37\%) w porównaniu z cementami samoadhezyjnymi, co jest spójne z danymi z piśmiennictwa (Bitter 2017, Majewski 2013).

Cementy samoadhezyjne, jak RelyX Unicem, wykazują niski efekt demineralizacji, pomimo niskiego początkowego $\mathrm{pH}$ materiału (De Munck 2004). Słaba demineralizacja zębiny może nie zwiększać dostatecznie powierzchni dla interakcji z cementem. W przypadku RelyX Unicem (odpowiednik RelyX U200), zaobserwowano, że materiał nałożony na złamaną zębinę oddziałuje tylko bardzo powierzchownie, bez wytworzenia zaczepów z żywicy. Strefa interakcji jest nieregularna, o grubości od 0 do $2 \mu \mathrm{m}$. Oddziaływanie RelyX Unicem z zębiną jest ledwo wykrywalne morfologicznie (Van Meerbeek 2003). Część badań wskazuje jednak na zbliżoną lub większą siłę wiązania materiałów samoadhezyjnych w porównaniu z konwencjonalnymi oraz samowytrawiającymi cementami na bazie żywic, tłumacząc uzyskane wyniki uproszczoną procedurą postępowania zmniejszającą wrażliwość zabiegu cementowania (Ebert 2011, Xu N 2011, Zaitter 2011).

Badania przeprowadzone przez Olczak i Pawlicką wykazały, że 56\% ankietowanych lekarzy dentystów do uszczelniania kanałów nadal używało pasty Endomethasone N (Olczak 2008). Wyniki badań własnych wskazują, że powierzchnie zanieczyszczone eugenolowym uszczelniaczem endodontycznym słabiej łączą się z materiałem cementującym wkład k-k (18,5-34\%). Obserwacje własne są potwierdzeniem wcześniejszych doniesień o negatywnym wpływie eugenolu na siłę wiązania w układzie wkład k-k - cement - zębina korzeniowa (Alfredo 2006). Również Dias, w teście na zrywanie metalowych wkładów standardowych, zaobserwował osłabienie wiązania cementów żywicznych w przypadku kanałów uszczelnionych materiałem na bazie eugenolu (Dias 2009).

W badaniach własnych porównanie charakteru powstałego niepowodzenia dla różnych grup cementów i uszczelniaczy kanałowych wykazało, że dla cementów samoadhezyjnych najsłabszym ogniwem jest łączenie na granicy cement-zębina, podczas gdy dla cementów stosowanych w technice total etch słabiej wypadało łączenie na granicy wkład-cement. Użycie uszczelniacza z zawartością eugenolu osłabiało wiązanie na granicy cement-zębina korzeniowa, skutkując większym odsetkiem przełomów o charakterze adhezyjnym typu
A1 (tabela 6). Również de Oliveira zaobserwował korelację pomiędzy uszczelniaczem kanałowym a rodzajem powstałego niepowodzenia w teście na zrywanie wkładu. W przypadku obturacji kanału pastą eugenolową i płukania jedynie solą fizjologiczną większość niepowodzeń miała charakter adhezyjny na granicy zębiny i cementu. Przeciwnie prezentowały się przełomy w grupie, gdzie kanały płukano alkoholem etylowym lub izopropylowym - większość niepowodzeń powstała na granicy cementu i wkładu (de Oliveira 2019). Jest to zbieżne z obserwacjami własnymi, gdzie dla cementu samoadhezyjnego RelyX U200 odnotowano 75\% przełomów A1 dla AH Plus i 87,5\% dla Endomethasone $\mathrm{N}$.

Wśród możliwych sposobów zwiększenia adhezji w kanałach uszczelnionych pastami na bazie eugenolu wymienia się: wytrawianie kanału 37\% kwasem ortofosforowym przez 60 sekund (Pérez 2014), płukanie alkoholem (etanolem, alkoholem izopropylowym) lub chlorheksydyną (de Oliveira 2019, Ferraz 2001). Tjan i Nemetz, badając wpływ uszczelniacza eugenolowego na retencję wkładów FRC osadzonych za pomocą cementu kompozytowego (Panavia EX), wykazali, że zarówno wytrawianie 37\% kwasem ortofosforowym, jak i płukanie alkoholem (etanolem) zwiększało odporność wkładów w teście na zrywanie, jednak płukanie alkoholem było bardziej skuteczne (Tjan 1992). De Oliveira, porównując skuteczność oczyszczania powierzchni zanieczyszczonej eugenolem 70\% alkoholem izopropylowym, 70\% etanolem i acetonem, zaobserwował, że żadna z tych substancji nie usuwała całkowicie pozostałości eugenolu. Etanol najefektywniej niwelował wpływ uszczelniacza kanałowego na użyty cement żywiczny (RelyX ARC, 3M ESPE). W tej grupie, w porównaniu z próbą kontrolną autor nie stwierdził osłabienia wiązania - wyniki były średnio o 10\% niższe, ale bez istotności statystycznej. W grupie zębów, w których kanały były płukane alkoholem izopropylowym, uzyskane wyniki były nieznacznie niższe (30\% w porównaniu z grupą kontrolną i 25\% w stosunku do płukania etanolem). Najmniej skuteczny okazał się aceton - oznaczone siły zrywu były średnio 40\% niższe niż w kanałach, których nie wypełniono pastą eugenolową. Siły zrywu wkładów FRC dla kanałów obturowanych uszczelniaczem na bazie eugenolu i płukanych wyłącznie solą fizjologiczną były o ponad $80 \%$ niższe, niż w grupie zębów, gdzie kanały zostały chemo-mechanicznie oczyszczone i pozostawione bez wypełnienia. Potencjał etanolu, alkoholu izopropylowego i acetonu do oczyszczania ścian kanału z resztek eugenolu wynika z faktu, że 
są to rozpuszczalniki bipolarne, które rozpuszczają zarówno związki polarne, jak i niepolarne (eugenol) - zgodnie z zasadą, że „podobne rozpuszcza podobne". Niecałkowite oczyszczenie ścian kanału z pozostałości uszczelniacza autor tłumaczy słabą rozpuszczalnością eugenolu w wodzie (70\% etanol zawiera wodę destylowaną). Z kolei nieznacznie słabsze działanie alkoholu izopropylowego, niż etylowego, pomimo podobnego składu obu alkoholi jest związane z niższą polarnością tego pierwszego. Na podstawie przeprowadzonych obserwacji autor nie zaleca stosowania acetonu do oczyszczania kanałów korzeniowych. Poza mniej efektywnym rozpuszczaniem resztek uszczelniacza może przyczyniać się do do hamowania tworzenia się jednorodnej warstwy hybrydowej ze względu na jego wysoką zdolność usuwania wody z podłoża, co powoduje zapadanie się włókien kolagenowych na skutek odwodnienia zębiny. Z kolei rozpuszczalność eugenolu w soli fizjologicznej jest podobna do rozpuszczalności tego związku w wodzie - ograniczona, co skutkuje pozostawieniem na ścianach kanału resztek uszczelniacza i najniższymi siłami uzyskiwanymi w teście na zrywanie wkładów k-k (de Oliveira 2019, Abate 2000). Badania własne potwierdziły, że 70\% alkohol izopropylowy skutecznie oczyszcza ściany kanału z resztek uszczelniacza eugenolowego, przyczyniając się do uzyskania większych sił zrywu o 10-26\% w porównaniu z kanałami płukanymi wodą destylowaną. Siły te pozostawały jednak o 10-15\% niższe niż w kanałach uszczelnionych AH Plus.

Na podstawie przeprowadzonych badań własnych i doniesień z piśmiennictwa można wnioskować, że w celu poprawienia adhezji, przypadku, gdy kanały zostały wypełnione Endomethasone $\mathrm{N}$, zalecane jest użycie konwencjonalnych cementów kompozytowych z wcześniejszym wytrawianiem ścian kanału oraz płukaniem alkoholem etylowym lub izopropylowym. Zastosowanie związków chlorheksydyny (np. 2\% żel) może dodatkowo wzmocnić wiązanie ze względu na jej udokumentowane działanie zwiększające adhezję materiałów kompozytowych. Badanie skaningowym mikroskopem elektronowym wykazało, że w wyniku stosowania 2\% żelu chlorheksydynowego otwarciu ulegają prawie wszystkie kanaliki zębinowe. Według Ferraza jest to wynikiem lepkości żelu, która sprzyja skuteczniejszemu oczyszczaniu mechanicznemu kanału korzeniowego oraz lepszemu usuwaniu resztek zębiny i pozostałej tkanki (Ferraz 2001). Również Lopes na podstawie przeprowadzonych badań zaleca, aby przed stosowaniem materiałów kompozytowych każdorazowo oczyszczać tkanki zęba 2\% żelem chlorheksydynowym w celu redukcji mikroprzecieku i zwiększenia trwałości odbudowy. Autor zaobserwował, że użycie chlorheksydyny korzystnie wpływa na adhezję i zmniejszenie mikroprzecieku nawet w sytuacjach, w których tkanki zęba nie miały wcześniej kontaktu z eugenolem (Lopes 2016).

\section{Wnioski}

Na podstawie przeprowadzonych badań można wysunąć następujące wnioski: (1) Eugenol zawarty w paście uszczelniającej znacząco obniża siłę wiązania cementów na bazie żywic, niezależnie od rodzaju użytego cementu. (2) Rodzaj użytego cementu adhezyjnego ma wpływ na siłę połączenia wkładu wzmacnianego włóknem szklanym z zębiną korzeniową. Cementy stosowane w technice total etch zapewniają do 20-37\% większe siły wiązania, niż materiały samoadhezyjne. (3) W przypadku zastosowania uszczelniaczy kanałowych zawierających eugenol, siłę wiązania cementów na bazie żywic można poprawić poprzez płukanie kanału 70\% alkoholem izopropylowym. Łączenie pozostaje jednak słabsze o około 10-15\% w porównaniu z próbami, w których kanały uszczelniono materiałami na bazie żywic epoksydowych.

\section{Oświadczenia}

Oświadczenie dotyczące konfliktu interesów Autorzy deklarują brak konfliktu interesów w autorstwie oraz publikacji pracy.

\section{Źródła finansowania}

Autorzy deklarują brak źródeł finansowania.

\section{Piśmiennictwo}

[1] Żarow M, Steinder J. Strategie odbudowy zębów bocznych po leczeniu endodontycznym na podstawie przypadku klinicznego. Annales Academiae Medicae Stetinensis. 2009;55(2):53-58.

[2] Vallittu P, Özcan M. Clinical Guide to Principles of Fiber-Reinforced Composites in Dentistry. Woodhead Publishing. 2017;97-107. English.

[3] Kacprzak-Ogłuszka M, Dejak B. Bond strength of glass fibre-reinforced posts with composite cement. Prosthodontics. 2018;68(2):232-242.

[4] Mierzwińska-Nastalska E, Szczyrek P. Uzupełnienia ceramiczne. Postępowanie kliniczne i wykonawstwo laboratoryjne. Med. Tour Press International 2011.

[5] Akkayan B. An in vitro study evaluating the effect of ferrule length on facture resistance of endodontically treated teeth restored with fiber-reinforced and zirconia dowel systems. Int J Prosthodont 2004;92:155-162. English.

[6] Dejak B. Kompendium wykonywania uzupełnień protetycznych. Med Tour Pres International, Otwock; 2014. s. 19-37. 
[7] Clavijo VG, Reis JM, Kabbach W, Silva AL, Oliveira Junior OB, Andrade MF. Fracture strength of flared bovine roots restored with different intraradicular posts. Journal of applied oral science. 2009;17(6): 574-578. English.

[8] Schmitter M, Hamadi K, Rammelsberg P. Survival of two post systems - Five-year results of a randomized clinical trial. Quintessence Int. 2011;42(10):843850. English.

[9] Monticelli F, Grandini S, Goracci C, Ferrari M. Clinical behavior of translucent-fiber posts: A 2-year prospective study International Journal of Prosthodontics. 2003;16(6):593-596. English.

[10] Bonfante G, Kaizer OB, Pegoraro LF, do Valle AL. Tensile bond strength of glass fiber posts luted with different cements. Brazilian Oral Research. 2007; 21:159-64. English.

[11] Bitter K, Maletic A, Neumann K, Breschi L, Sterzenbach G, Taschner M. Adhesive Durability Inside the Root Canal Using Self-adhesive Resin Cements for Luting Fiber Posts. Operative Dentistry. 2017;42(6): E167-E176. English.

[12] Majewski WS, Pryliński M. Materiały i technologie współczesnej protetyki stomatologicznej Wyd. Czelej, Lublin; 2013, wyd.1. s. 105-111.

[13] De Munck J, Vargas M, Van Landuyt K, Hikita K, Lambrechts P, Van Meerbeek B. Bonding of an autoadhesive luting material to enamel and dentin. Dent Mat. 2004;20:963-71. English.

[14] Van Meerbeek B, De Munck J, Yoshida Y, Inoue S, Vargas M, Vijay P, Van Landuyt K, Lambrechts P, Vanherle $\mathrm{G}$. Buonocore memorial lecture. Adhesion to enamel and dentin: current status and future challenges. Oper Dent. 200;28:215-235. English.

[15] Ebert J, Leyer A, Gunther O, Lohbauer U, Petschelt A, Frankenberger R, Roggendorf MJ. Bond strength of adhesive cements to root canal dentin tested with a novel pull-out approach. J Endod. 2011;37:15581561. English.

[16] Xu N, Hu SH, Yang Y, Ren X, Zuo EJ. Effect of different resin cements and silane coupling agents on bond strength of glass fiber post to root dentin. J Dalian Med Univ. 2011;33:321-324. English.

[17] Zaitter S, Sousa-Neto MD, Roperto RC, Silva-Sousa YT, El-Mowafy O. Microtensile bond strength of glass fiber posts cemented with self-adhesiv and self-etching resin cements. J Adhes Dent. 2011 Feb;13(1):55-9. English.

[18] Olczak K, Pawlicka H. Materiały i środki stosowane przez lekarzy dentystów podczas leczenia endodontycznego - badanie ankietowe. Czas. Stomatol. 2008;61:851-857.
[19] Alfredo E, Souza ES, Marchesan MA, Paulino SM, Gariba-Silva R, Souza-Neto MD. Effect of eugenol based endodontic cement on the adhesion of intraradicular posts. Braz Dent J. 2006;17:130-133. English.

[20] Dias LL, Giovani AR, Silva Sousa YT, Vansan LP, Alfredo E, Sousa-Neto MD, Paulino SM. Effect of eugenol-based endodontic sealer on the adhesion of intraradicular posts cemented after different periods. J Appl Oral Sci. 2009 Nov-Dec;17(6):579-83. English.

[21] Pérez MA, Guerrero IJ, Celis RL. Effect of residual eugenol in root canals on adhesion of prefabricated light-transmitting endodontic posts cemented with composite resin. Rev Odont Mex. 2014;18(1):14-18. English.

[22] de Oliveira E, Cecchin D, Miyagaki DC, de Moura A LC, Disarz A, Souza MA, Farina AP. Effect of different protocols of eugenol removal on the bond strength between the fibre post and root dentin. Aust Endod J. 2019 Aug; 45(2):177-183. English.

[23] Ferraz CC, Gomes BP, Zaia AA. In vitro assessment of the antimicrobial action and the mechanical ability of chlorhexidine gel as an endodontic irrigant. J Endod. 2001;27:452-5. English.

[24] Tjan AH, Nemetz H. Effect of eugenol-containing endodontic sealer on retention of prefabricated posts luted with adhesive composite resin cement. Quintessence Int. 1992 Dec; 23(12):839-44. English.

[25] Abate PF, Rodriguez VI, Macchi RL. Evaporation of solvent in one-bottle adhesives. J Dent 2000;28: 437-40. English.

[26] Lopes MB, Felizardo KR, Kaneshima RH. Influence of eugenol-based materials and cleaning procedures previously to resin composite restoration on microleakage after 1-year storage. Appl Adhes Sci. 4, 15 (2016). English.

Zaakceptowano do edycji: 28.06.21 Zaakceptowano do publikacji: 29.09.21

Adres do korespondencji:

Yasmin Bartosik

tel.: 793450419

e-mail:yasminfillat@gmail.com 